\title{
Designing Effective Teaching Interventions with Semantic Annotation
}

\author{
Zainb Dawod and David Bell \\ College of Engineering Design and Physical Sciences \\ Department of Computer Science \\ Brunel University \\ Uxbridge, UB8 3PH, United Kingdom \\ \{zainb.dawod, David.Bell\}@brunel.ac.uk
}

\begin{abstract}
Semantic web technology promises a number of benefits for a future in many different fields and especially within education. There is, however, a considerable gap in Semantic Web research between the contributions in the educational field and the research carried out in the special educational needs area. Semantic web techniques have been applied in education to retrieve the relevant material, and add semantic annotation to documents. However, special needs schools still rely heavily on manual methods. This paper presents a design of SEN teaching platform based on a semantic web annotation tool (Amaya) coordinated with a web application. This design evaluated by conducting pilot study in schools caring for special needs students SEN.

Building on a pilot study at two schools and interviewing nine participants (Teachers, Teaching Assistant) in UK, the findings indicate that Semantic Web technology can benefit the education of special needs by utilizing semantic web annotation tools.
\end{abstract}

Keywords: Semantic web· Semantic web annotation (Amaya) $\cdot$ Special Educational Needs $(\mathrm{SEN}) \cdot$ Design Educational Platform $•$ Effective Teaching

\section{Introduction}

Rapid evolution of the World Wide Web has attempted to support a variety of users in different fields and contexts with different requirements and experiences such as, elearning, distance learning, digital libraries and medical field. The Semantic Web initiative could have an impact on educational research with a number of promising characteristics such as allowing data to be shared and reuse by the teaching staff and students. There is, however, a considerable gap in Semantic Web research between the contributions in the educational field and the research carried out in the special educational needs field. The teaching methods available in a special needs school typically utilise manual methods. This paper examines the impact of Semantic Web Annotation tool (Amaya) on enhancing their educational performance. Consequently, the motivations for promoting semantic web annotation tools in the education of special needs motivated the design of a new system which could support varied

adfa, p. 1, 2016.

(C) Springer-Verlag Berlin Heidelberg 2016 
special needs students. The new system - SEN Teaching Platform (STP) - synthesises the core Web language for creating applications (HTML) and semantic Web Annotation Tool (Amaya). Concerning the STP design, a set of criteria are based on the previous research in paper [4]. This earlier experiment tested different annotation tools and selected Amaya as a most suitable tool to conduct further work in schools. A major concern from this earlier study was to allow the STP model to consider the important factors and barriers that might influence semantic web annotation adoption.

The identified criteria for a proposed STP focused on designing a teaching platform that is easy to use; support/replace the current manual teaching methods, coordinate with different abilities and requirements and available as required. The experimental content used in this study and implemented in the STP is poetry. Poetry is used in the design because it has certain qualities that make it an excellent vehicle through which to teach SEN students. Poems that rhyme offer an excellent opportunity to listen for and find rhyming words [5]. Consequently, it is one of the more difficult areas to understand for special needs students especially students with ASD [11]. Poetry has a sizable vocabulary with underlying meanings that are especially difficult for autistic students [6].

Twenty five schools were contacted to volunteer for this research. The target age group in this research is two and a half to sixteen years old. Two schools offered to participate in this study (Nursery, Special needs High School). Building on a comprehensive pilot study at two schools accommodating special needs students in the UK, nine interviews were conducted with teaching staff (teachers and teaching assistant) to experience and understand their personal point of view. All of the data gathered from the two schools was thematically analysed resulting in a design brief that has a number of required elements. Firstly, communications including engaging students, increasing the concentration and reducing behavior problems. Secondly, understanding certain words, especially for autistic students, and accommodate different abilities in class using visual resources are important for greater understanding. Finally, class management, resources availability as required and staff training are important to prepare each lesson for special needs. The pilot study examines all these categories with their themes using the SEN Teaching Platform (STP). STP proved to be a useful tool in enhancing SEN teaching.

The study follows a design science research approach composed of three phases. The first phase "Identify and build the STP", is accomplished in three steps. The first step started by identifying the problem area from literature and the previous research [3]. Secondly, a vision was formulated and feasibility study undertaken that includes identifying the participant (Teaching staff) requirements and understanding the special needs student requirements. Thirdly, preparing and scoping stage to design the STP. Designing STP include design an educational poetry website imported into Amaya. In the second phase, Semantic annotation was applied to poetry from the first step. This process includes annotating all the poems with different types of annotations. The annotations included are the symbol systems currently used for special needs (Makaton, Widget and Picture Exchange Communication System PECS), images, sound and information [10,4]. The second step involved conducting data collection and filtering. This process itself includes managing the required information which 
includes all the data gathered from the participant's interview, class observations and field's notes. All the data gathered is then thematically analysed. The last phase is evaluating the STP performance to see if it achieved the design targets/ criteria.

The findings indicate that Semantic Web technology can benefit the education of special needs by utilizing semantic web annotation tools. The semantic web annotation tool (Amaya) has a considerable impact on enhancing their educational performance and reducing the effort required from the teaching staff to design and prepare for each lesson. All participants chose to use STP and recognised the benefit of STP. However, some recommendations suggested improvement that could be made.

\section{Research Design and Platform Process}

The study follows a design research approach through which learning of the problem space is accomplished through artefact evolvement and evaluation. Hevner [7] described the process as an effective solution to a problem. Effective solutions may not match with the optimum result. The effectiveness of the solution must be provable through an iterative evaluation of the design artifact(s). The artefact resulting from the Design Science Research (DSR) in this work was to induce the characterisation of the new STP model from observation of practice. The process which derives the discovery of semantic web annotation technique to design SEN Teaching Platform (STP) is refining and extending the structure of the website produced in [4]. The input for the first step is the poetry website and the output will be the refined poetry website which will be the input for the second step. In second step manual annotation using Amaya will be conducted which produced poetry annotated website. This website will be the input for the participant's requirement in order to modify according to the teachers lesson requirements. This annotated website with the consideration of the participant's requirement will be input for the final step to produce the STP as described in table 1 .

Table 1. Iteration Steps- Input Output Model

\begin{tabular}{|c|l|l|l|}
\hline \multicolumn{1}{|c|}{ Steps } & \multicolumn{1}{|c|}{ Method } & \multicolumn{1}{|c|}{ Input artefacts } & Output \\
\hline $\begin{array}{l}\text { 1. Refine and extend } \\
\text { the structure of the } \\
\text { website }\end{array}$ & $\begin{array}{l}\text { Build, amend and } \\
\text { extend HTML } \\
\text { Website }\end{array}$ & $\begin{array}{l}\text { Poetry Website, } \\
\text { Anotea/Amaya, Mozilla } \\
\text { browser, images, SEN } \\
\text { symbols }\end{array}$ & $\begin{array}{l}\text { Improved HTML } \\
\text { Poetry website } \\
\text { (Model)\&(Method) } \\
\text { (Instantiation) }\end{array}$ \\
\hline $\begin{array}{l}\text { 2. Identify the text } \\
\text { required for } \\
\text { annotation/type of } \\
\text { annotation }\end{array}$ & $\begin{array}{l}\text { Manual } \\
\text { annotation }\end{array}$ & $\begin{array}{l}\text { Improved HTML Poetry } \\
\text { website } \\
\text { (Model)\&(Method) } \\
\text { (Instantiation) }\end{array}$ & $\begin{array}{l}\text { Annotated } \\
\text { text(Method) }\end{array}$ \\
\hline $\begin{array}{l}\text { 3. Identify the teaching } \\
\text { staff requirements to } \\
\text { teach poems }\end{array}$ & $\begin{array}{l}\text { Interview (Semi } \\
\text { structured } \\
\text { interview } \\
\text { questions) }\end{array}$ & Annotated text(Method) & $\begin{array}{l}\text { The teaching staff } \\
\text { requirements for } \\
\text { teaching poems (STP } \\
\text { Model) }\end{array}$ \\
\hline $\begin{array}{l}\text { 4. Develop and extend } \\
\text { the STP model by } \\
\text { incorporating the } \\
\text { current symbol }\end{array}$ & $\begin{array}{l}\text { Build Amaya } \\
\text { Application }\end{array}$ & Web service artefact/STP & $\begin{array}{l}\text { Prototype application } \\
\text { (Instantiation) } \\
\text { New STP }\end{array}$ \\
\hline
\end{tabular}




\begin{tabular}{|l|l|l|l|}
\hline Steps & Method & Input artefacts & Output \\
\hline $\begin{array}{l}\text { systems used to } \\
\text { support SEN students } \\
\text { and variety of SEN } \\
\text { needs }\end{array}$ & & & \\
\hline
\end{tabular}

\section{$3 \quad$ Artefact Building and Development (Pilot Study)}

The STP Design proposed is based on the findings from the previous work of [4] study. The study was based on literature review and the experiment conducted on two tools and results in choosing Amaya for this study. Hence, a set of evaluation criteria listed for the proposed STP in this study.

1. The platform model should be simple to use to make the platform model usable by staff with different IT skills and to avoid any technical problems.

2. The platform model should support the staff with the class management skills, including the ability to reduce behaviour problems and increase student's engagement level in class.

3. The STP model should be able to support/replace the manual methods as a huge effort required to prepare lessons.

4. The STP should include the symbol systems currently used for helping SEN in schools to assist with symbol systems training.

5. The platform model should support/replace the symbol cards existent.

6. The platform model should coordinate with different abilities and needs.

7. The platform model should improve the understanding the poems, since poetry is one of the difficult topics to explain for SEN students.

8. The platform model should have flexibility to benefit in different subjects.

9. The platform model should increase the student's motivation and engagement in class.

10. The platform model should be easy to use, edit and maintain.

11. The platform model should offer different types of annotations (image, information, bigger text, sound and symbols).

12. The platform saved on the local server at this stage because some schools have no internet in class.

\subsection{Data Collection}

This section covers all activities to produce the platform assessment. The primary goal of data collection is to prepare data for assessing the STP model. The data used in this study was collected from February 2012 to October 2012. The particular technique used to collect the data was through a series of semi-structured inter-views. The interviews provide the opportunity to explore that cannot be directly observed from the participants' or the researcher point of view [8, 12]. In this study, data collection activities described as follows:

\section{Participants Recruitments}


Pilot study interviews were carried out in two schools, a nursery for children ages 3-5 years and a secondary school for children ages 11-16 years. The interviews con-ducted with nine participants. They sampled according to two categories, two Teachers and seven Teaching assistants. Table 2. Illustrates the composition of the interviewee sample across the two schools.

Table 2. Participants overall description in the Pilot Study

\begin{tabular}{|l|l|}
\hline Description & Total \\
\hline Sample Size & 9 \\
\hline Gender & \\
Female & 9 \\
\hline Age Range SEN Children & $(2.5-4),(11-16)$ \\
\hline Preschool (2.5-4) & 5 \\
Manager/Staff Teacher & 1 \\
Teaching Staff & 4 \\
\hline Secondary School (11- & 4 \\
16) & 1 \\
SEN Teacher & 3 \\
Teaching Assistant & \\
\hline
\end{tabular}

\section{Extended Amaya and STP Implementation}

This section presents a demonstration of the practical application of STP with the use of the semantic annotation (Amaya). First, the class teacher chooses the poem and the type of annotation required for the class demonstration. The platform prepared accordingly with the kind of annotation required. The annotation offered will be in a wide range depending on the SEN age and needs. In this study "The Zoo" selected for the Nursery school without any changes suggested. "Bed Time" poem was chosen by the secondary class teacher with symbol annotation requirement for the class and image annotation for one-to-one support. Figure 1 presents the first user interface of STP. Figure 2 presents the poem page with different styles of poems depending on the age and style. Figure 3 presents the children poems page with various types of poems that can be changed according to the class requirements. 


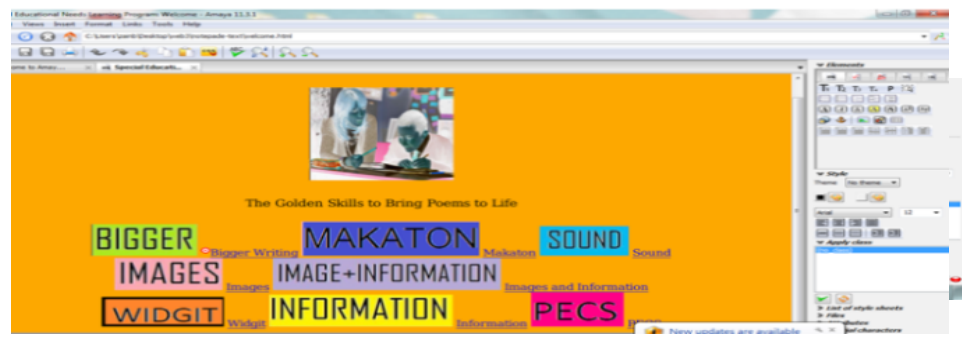

Fig. 1. STP user Interface

Fig. 2. Different styles of poems

Fig. 3. The children poem home page

When the teacher clicks on the pen mark as illustrated in figure 4. "The Zoo" is the poem tested in the pre-school caring for special educational needs as illustrated in Figure 5.
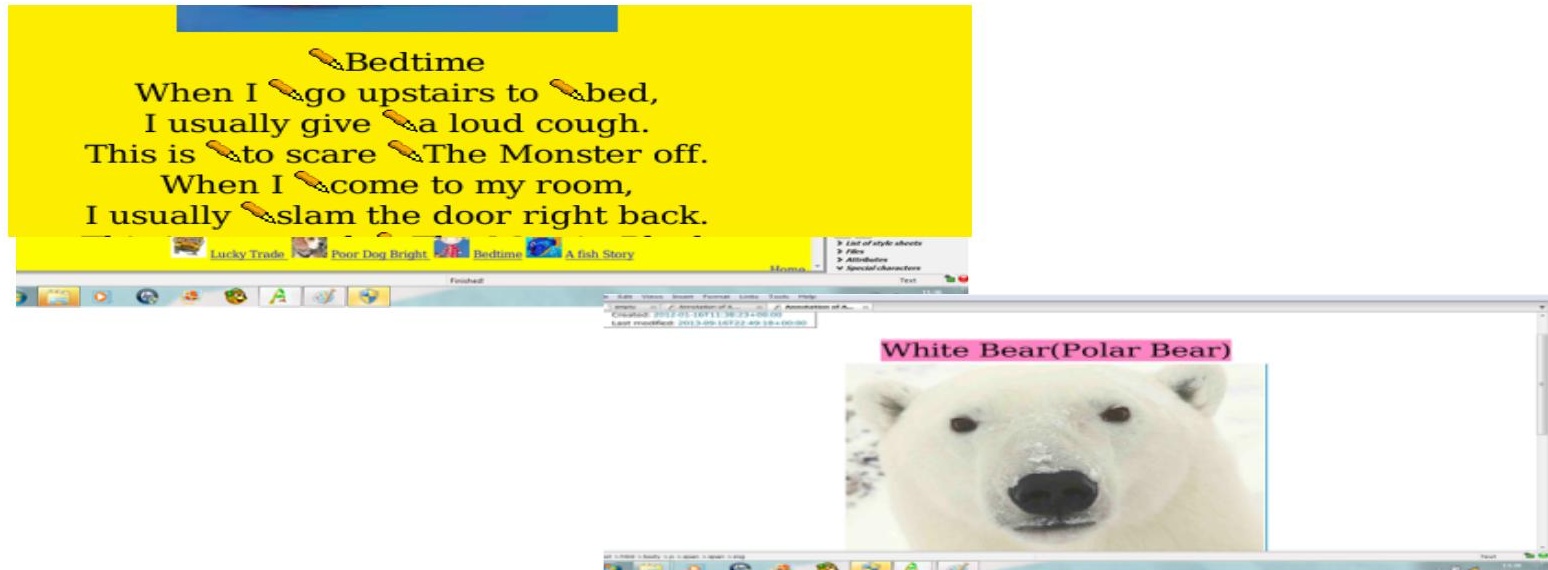

Fig. 4. The screenshot of Amaya annotation penci

Fig. 5. The result of clicking the word 'Polar bear'

\section{Analysis, Results and Discussion}

In this study, the data collected was thematically analysed. The results grouped into common themes in the following sections to facilitate comparison between the categories.

\subsection{Adopting Thematic Analysis as a Research Approach}

The practical purpose of this analysis is to confirm and evaluate the STP design with Amaya annotation tool technology. Step one in developing the analysis plan for this research is to be familiarised with the data. Data familiarization through the transcription process, by listening to the interviews and reading through the data, while thinking about possible themes [1]. Thereafter, first codes generated 
from the transcript information [2]. Qualitative data analysis software NVivo10, used to facilitate the thematic analysis in the pilot study. All the data exported to NVivo10, which coded the interesting features of the entire dataset. Additionally, identify themes and review them. Each theme captures something important about the data in relation to research questions. All the data relevant to each theme is extracted to ensure all the relevant data are connected first with individual codes and then with the theme. This process will build a framework of themes to show the connections and relationships between themes and subthemes [1]. Table 3 outlines the eight codes, themes and sub-Themes along with the number of times each theme and sub-theme was mentioned by the participants.

Table 3. Open-Coding Concepts Categorisation

\begin{tabular}{|c|c|c|c|}
\hline CODES & Themes & SUB-THEMES & DEFINITION \\
\hline $\begin{array}{l}\text { Current } \\
\text { Teaching } \\
\text { Methods }\end{array}$ & $\begin{array}{l}\text {-Manual Methods } \\
\text { (93), computer } \\
\text { programs /Internet (9), } \\
\text { Time Consuming (5), } \\
\text { Preparation Demands } \\
\text { (4), Visual (5), } \\
\text { Required Individual } \\
\text { Support Required } \\
\text { more staff (1) }\end{array}$ & $\begin{array}{l}\text { - Computer programs (4), internet (4), Visual } \\
\text { using Images(18), Symbol Systems(6), } \\
\text { Designed Booklet (5) and document created } \\
\text { (1) }\end{array}$ & $\begin{array}{l}\text { What is the scope } \\
\text { of study? Explore } \\
\text { the current } \\
\text { teaching methods } \\
\text { used in schools } \\
\text { for SEN. }\end{array}$ \\
\hline $\begin{array}{l}\text { Understan } \\
\text { ding } \\
\text { Current } \\
\text { Teaching } \\
\text { Requireme } \\
\text { nt }\end{array}$ & $\begin{array}{l}\text {-Support Teaching } \\
\text { Staff, Understanding } \\
\text { (5), Resources(42), } \\
\text { Time (9), Support (2), } \\
\text { Visual, Class } \\
\text { Management, } \\
\text { Staffing(2), } \\
\text { Communication And } \\
\text { Language(2), Personal } \\
\text { Social And Emotional } \\
\text { (2), ASD, Learning } \\
\text { Progress(2) }\end{array}$ & $\begin{array}{l}\text {-Understand Underline Meaning (9), SEN } \\
\text { Understanding Poems (5), Behavioural } \\
\text { Problems (9), Time Demand (9), } \\
\text { Preparation(6), Accommodate Different } \\
\text { Abilities (2), Reading (4), Numeracy (1), } \\
\text { Writing (1), Communication (3), Engaging } \\
\text { (2), Lack Of Staff(5), Training (6), } \\
\text { Organization (4), SEN Mood (4) } \\
\text {-English As A Second Language (1), Support } \\
\text { ASD(2), Concentration(1) }\end{array}$ & $\begin{array}{l}\text { Understand the } \\
\text { current teaching } \\
\text { needs and what } \\
\text { they require } \\
\text { Managing and } \\
\text { interpreting the } \\
\text { SEN and teaching } \\
\text { staff requirements }\end{array}$ \\
\hline $\begin{array}{l}\text { Important } \\
\text { Teaching } \\
\text { Factors } \\
\text { For SEN } \\
\text { In School }\end{array}$ & $\begin{array}{l}\text {-Resources, Class } \\
\text { Management, } \\
\text { Understanding, Group } \\
\text { Size (One To One Or } \\
\text { Small Group), } \\
\text { Communication(2), } \\
\text { Personal Social And } \\
\text { Emotional }\end{array}$ & $\begin{array}{l}\text {-Concentration (1), Understand Underline } \\
\text { Meaning(1), Differentiation (1), Routine(1) } \\
\text {-Visual(5), Time Management(1), } \\
\text { Prepared(1), Engaging (2), Demonstration } \\
\text { Layout (5), Working In Small Groups Or } \\
\text { One To One (5), Resource Layout(2), } \\
\text { Mood(4), Poems(7), Language(3), Simple } \\
\text { and short poems(2) }\end{array}$ & $\begin{array}{l}\text { Categorise the } \\
\text { demands based on } \\
\text { requirements } \\
\text { Managing and } \\
\text { interpreting the } \\
\text { SEN students } \\
\text { requirements }\end{array}$ \\
\hline Poems & $\begin{array}{l}\text {-Importance, Support, } \\
\text { Difficult }\end{array}$ & $\begin{array}{l}\text {-Essential For Pre-School(1) } \\
\text {-Support SEN Students In Teaching And } \\
\text { Learning(2), Supports With Talk (1), Can } \\
\text { Teach All Subject In Pre-School (2), } \\
\text { Difficult To Explain The Underline Meaning } \\
\text { (2) }\end{array}$ & $\begin{array}{l}\text { Categorise } \\
\text { demands }\end{array}$ \\
\hline ASD & $\begin{array}{l}\text {-Resources, Class } \\
\text { Management }\end{array}$ & $\begin{array}{l}\text {-Concentration(1), Understand } \\
\text { Meaning(1), Routine, Visual, Prepared, } \\
\text { Demonstration Layout }\end{array}$ & $\begin{array}{l}\text { Categorise the } \\
\text { demands } \\
\text { Managing and } \\
\text { interpreting the } \\
\text { ASD requirements }\end{array}$ \\
\hline
\end{tabular}




\begin{tabular}{|c|c|c|c|}
\hline CODES & Themes & SUB-THEMES & DEFINITION \\
\hline $\begin{array}{l}\text { The Use } \\
\text { Of } \\
\text { Semantic } \\
\text { Web } \\
\text { Annotatio } \\
\text { n Tool } \\
\text { (SEN } \\
\text { Teaching } \\
\text { Prototype) }\end{array}$ & $\begin{array}{l}\text {-Aid All Types Of } \\
\text { Sen(9), Preparation } \\
\text { (3), Class } \\
\text { Management(16), } \\
\text { Resources, Setting } \\
\text { (Sen Mood), Teaching, } \\
\text { ASD(4), } \\
\text { Concentration(2), } \\
\text { Learning Process } \\
\text { (150), Availability (1), } \\
\text { Support (6) }\end{array}$ & $\begin{array}{l}\text {-Understanding (6), Support With } \\
\text { Preparation (5), Reduce Pressure On } \\
\text { Teaching Staff(10), Support Teaching Staff } \\
\text { (5), Save Preparation Time (7), Help With } \\
\text { Staffing Problems (Lack Of Staff) (4), } \\
\text { Support For Autistic (ASD) Children (5), } \\
\text { Accommodate Different Abilities (16) } \\
\text { - Support/Replace Re-sources(11), can } \\
\text { replace cards(1), Support Manual Methods } \\
\text { (6), Reduce Behavioural Problems(7), Better } \\
\text { Mood, Support With Reading, Differentiate } \\
\text { Numeracy, Can Be Used For Different } \\
\text { Subject (25), Can Support ASD (12), Better } \\
\text { Concentration(2), Effective Learning (216), } \\
\text { Useful In Teaching Poems (7), } \\
\text { Motivation(11), Writing(2), Engaging(1), } \\
\text { Better teaching results(4) }\end{array}$ & $\begin{array}{lr}\text { Undertake } & \text { pilot } \\
\text { research } & \text { and } \\
\text { Evaluating } & \text { SEN } \\
\text { prototype } & \text { in } \\
\text { schools } & \end{array}$ \\
\hline Evaluation & $\begin{array}{l}\text {-Layout (8), Content } \\
\text { (9), Participants } \\
\text { Suggestions For } \\
\text { Future Work }\end{array}$ & $\begin{array}{l}\text {-Bright Colours (4), Suitable Font and } \\
\text { colour (4), Short Rhymes (2), Images(1), } \\
\text { Bigger Images (4), Adapted To Younger age } \\
\text { (11), Adapted To Be Used By SEN } \\
\text { Independently(2), Special Version For } \\
\text { Teachers (1), Can Be Used For Different } \\
\text { Subjects Such As Maths (1), Popular } \\
\text { Characters Within The Prototype (1), Use } \\
\text { real pictures(1), Small Text (2), To Have A } \\
\text { Choice Of Annotate Words Or Lines(7_), } \\
\text { Use different languages for annotation (1), } \\
\text { Choose to use it in future (9) }\end{array}$ & $\begin{array}{l}\text { Evaluate } \\
\text { prototype if it } \\
\text { support the } \\
\text { teaching staff and } \\
\text { enhance the } \\
\text { teaching and } \\
\text { learning of poems } \\
\text { in class }\end{array}$ \\
\hline
\end{tabular}

During the interviews, participants identified various ways of teaching poems which is either using the computer or the manual way. The theme for current teaching method among these categories is labelled Current Teaching Methods. The observation shows that using images is the method that all participants use in their teaching. Moreover, from reviewing the participant's interviews it shows that current teaching methods requires time, preparation, and it should be visual. The participants signposted the current teaching requirements during the interviews by expressing their current concerns, current issues and the main issues in teaching SEN. The theme for the requirements is labelled understanding current teaching requirement.

A key issue observed from participants was that behavior problems, time, preparation and the underline meaning, in addition to other concerns such as staffing and understanding. Concurrently, the need for different ways of learning to increase understanding and to improve SEN mood was expressed by most of the participants. Finally, most of the participants pinpointed ASD as a major issues required effort to manage in SEN class.

It was observed through the interviews that the participants felt that Autistic is one of the main factors require attention in SEN schools. Another observation was the change faced by the teaching staff with an autistic child who has a short concentration time, difficult to understand underline meaning and can work in small groups. 
The interviews reflect on the suitability of using STP in teaching poems to SEN students. The observation made from group demonstration and one-to-one support during assessments with worksheets.

Several principal themes developed during coding through the links among categories. Moreover, the interview observation of the main points that participants focused on which have more impact on SEN teaching and learning. The results from the coding outlines the scope of the research that was pinpointed main themes required to achieve for the new STP design. Table 4 presents nine themes assigned to three categories of dimension 2: SEN students and teaching staff interaction.

Table 4. Categories and themes relating to SEN and teaching staff interaction

\begin{tabular}{|l|l|}
\hline \multicolumn{1}{|c|}{ Category } & Theme \\
\hline 5.5.2 Communication & 1. Engaging \\
& 2. Concentration \\
& 3.behaviour problems \\
\hline $\mathbf{5 . 5 . 3}$ Understanding & 1. understand underline words \\
& 2. Accommodate different abilities \\
& 3.visual resources \\
\hline $\mathbf{5 . 5 . 4}$ Preparation & 2. management \\
& 3. resource availability \\
& 4. staff training \\
\hline
\end{tabular}

Communication. The themes in Communication category was 'Engaging', 'Concentration' and 'Behavior problems'. These themes secured agreement from all the participants. The teaching assistant from the special school express the significance of engaging, concentration in the progress of learning for the whole class.

TA1: "obviously behavioral of certain students because if one student not doing what he supposed doing, it has effect on the rest of the class, but once you actually get to know that child"

Understanding. Theme one gained shared agreement from the participants on understands underline words especially with poems. The teacher from the special school expressed the difficulty of Autistic students to understand the underline words as follows;

"They understand it face value as it is literal not the underlining meaning of what the authors trying to get out, that is quiet difficult for them to understand" "To understand the underline meaning in the poem, so with some of our ASD pupil they would understand what they read as literal"

Theme two shows the significance of accommodating different abilities in class. The general opinion was that the teaching resources should benefit all types of abilities as clarified in the interview feedback below:

"To support with behavior...yhaa... Umm and understanding for the ones that have low understanding or communication problems"

Theme three, expressed strong opinion of all the participants that SEN students can understanding required visual resources as labelled by the teacher from the special secondary 
"Which of the above you consider more important for this type of support? "Visuals..images..visuals..visual images"

Preparation. Theme one in preparation category was management which is raised as main issue by all the participants. The teachers expressed their needs for staffing, time and resources to manage the load of preparation required before each lesson as expressed by the teaching assistant.

TA3: "pause.., no there aren't enough hours in the day so, times, because there is always lots of preparation to do and lot of things to get ready and resources, they will never be enough resources no matter how much you got, you will always".

Resource availability is the second theme raised by the teaching assistant which said:

TA1: "well in my class in particular, we have a lot of ASD students, so it's making sure that we have all of the work set beforehand, so if we have to do a class lesson with the whole group has to listen? We just have to make sure that we have everything ready, first thing for the ASD students, and prepare them what have to be next because you want to include everybody into the lesson if we can, so just preparation"

Research participants pointed to the staff training as an important issue to teach SEN students as said below:

TA3: "yes, definitely because (student) does Makaton, I picked up a bit of it but I never done it, I wish I had".

\subsection{Evaluation of STP}

The new STP designed is evaluated according to the criteria and the results from the thematic analysis. The STP can accomplish all the criteria as illustrated in Table 6 below:

Table 1. STP evaluation findings 


\begin{tabular}{|c|c|}
\hline Criteria & STP \\
\hline 1. Simple to use & $\checkmark$ \\
\hline 2. $\quad$ Support the staff with the class management skills & ป \\
\hline 3. $\quad$ Support/replace the manual methods & $\sqrt{ }$ \\
\hline 4. $\quad$ Saving preparation time & $\checkmark$ \\
\hline $\begin{array}{ll}\text { 5. } & \text { Support/replace the symbol cards }\end{array}$ & $\sqrt{ }$ \\
\hline 6. $\quad$ Support different types of SEN students' needs and abilities & $\sqrt{ }$ \\
\hline 7. $\quad$ Understanding & $\sqrt{ }$ \\
\hline 8. $\quad$ Utilised for other class subjects (flexible) & $\sqrt{ }$ \\
\hline 9. Increase the motivation and engagement & $\sqrt{ }$ \\
\hline 10. Easy to use, edit and maintain & $\sqrt{ }$ \\
\hline 11. Offer different types of annotations (image, information, bigger text, sound and symbols) & $\checkmark$ \\
\hline 1. $\quad$ Saved on local server & $\sqrt{1}$ \\
\hline
\end{tabular}

Although all the participants found the STP to be a useful resource for enhancing SEN education. There are some recommendations mentioned by the participants to improve the design of the STP such as bright colours, bigger font, short poems, more images.

\section{Conclusion and Future Works}

There is a considerable gap in Semantic Web research between the contributions in the educational field and the research carried out in the special educational needs field. The teaching methods available in a special needs school are typically based on manual methods. This paper examines the impact of Semantic Web Annotation tool (Amaya) on enhancing their educational performance - designing educational content. Consequently, the motivations for promoting semantic web annotation tools in the education of special needs motivated a design of a new system which could support special needs education. The new system - SEN Teaching Platform (STP) synthesises of the core Web language for creating applications (HTML) and semantic Web Annotation Tool (Amaya).

The study follows a design science research approach composed of three phases. The first phase "Identify and build the STP", is accomplished in three steps. The first step started by identifying the problem area from literature and the previous research [3]. Secondly, a vision was formulated and feasibility study undertaken that includes identifying the participant (Teaching staff) requirements and understanding the special needs student requirements. Thirdly, preparing and scoping stage to design the STP. Designing STP include design an educational poetry website imported into Amaya. In the second phase, Semantic annotation was applied to poetry from the first step. This process includes annotating all the poems with different types of annotations. The annotations included are the symbol systems currently used for special needs (Makaton, Widget and PECS), images, sound and information. The second step involved conducting data collection and filtering. This process includes managing the required information which includes all the data gathered from the participant's interview, class observations and field's notes. All the data gathered will be 
thematically analysed. The last phase is evaluating the STP performance to see if it achieved the design targets/ criteria.

\section{References}

1. Braun,V. and Clarke, V.: Using thematic analysis in psychology. Qualitative Research in Psychology. 3(2). pp. 77-101. ISSN 1478-0887. (2006)

2. Braun, V. and Clarke, V.: Teaching Thematic Analysis, look at overcoming challenges and developing strategies for effective learning. 26(2). pp. 9120124. (2013)

3. Communication Matters: Using Symbols and Communication. ISAAC (UK) (2012)

4. Dawod, Z.,Bell,D.: Adaptive Special educational needs (SEN) education on the Semantic Web, Proceedings of the U.K. Academy for Information Systems, 16th Annual Conference (2011)

5. Dillon, W.: Using Poetry in Teaching Reading to Special Education Students. Yale-New Haven Teachers Institute (2016). Accessed 8 February 2016

6. Gill, P., Stewart, K., Treasure, E. \& Chadwick, B.: Methods of data collection in qualitative research: interviews and focus groups, British Dental Journal 204, pp.291 - 295. (2008)

7. Hevner, A., March, S., Park, J., and Ram, S.: Design Science in Information Systems Research, MIS Quarterly (28:1) 2004, pp. 75-105 (2004)

8. Maxwell, J.A.: Designing a Qualitative Study, Chapter 7, PP. 214-253 (2008). http://www.sagepub.com/upm-data/23772_Ch7.pdf.

9. Osteen, M.: Autism and Representation. Routledge: Tailor \& Francis Group (2008)

10. Published online: 22 March 2008 doi:10.1038/bdj.2008.192. http://www.nature.com/bdj/journal/v204/n6/full/bdj.2008.192.html

11. Punch, K.F. Introduction to Social Research: Quantitative and Qualitative Approaches. Thousand Oaks: Sage (1998)

12. Khandkar, S.H.: Open Coding, pp. 1-9 (2014). : http://pages.cpsc.ucalgary.ca/ saul/wiki/uploads/CPSC681/open-coding.pdf. Accessed 26 October 2014

13. Slimani, T.: Semantic Annotation: The Mainstay of Semantic Web (2013)

14. Randi,J., Newman,T., and Grigorenko, L.E.: Teaching Children with Autism to Read for Meaning: Challenges and Possibilities. 40(7). PP. 890-902 (2010) 